\title{
Debate Background on the "Neo Romantic Period" in the Soviet Literary Research of the 1960-1980s
}

\author{
Kirill Nikolaevich Ankudinov \\ Uchuzhuk Maskhudovich Panesh \\ Kutas Nukhovna Paranuk \\ Galina Viktorovna Sokolova
}

Federal State Budget Institution of Higher Professional Education «Adyghe State University» (ASU), 385000 Maikop, street Pervomayskaya, 208, Russian Federation; Email: nisadgu@yandex.ru

Doi:10.5901/mjss.2015.v6n5s2p191

\begin{abstract}
The article is a local research related to the solution of the general theoretical literary issue: whether Romanticism is beyond Romanticism boundaries as a certain historical trend. The article reveals the methodology of solving this problem that combines the achievements of 'sociological' and 'formal' national schools of literary research, as well as uses the method of philosophical metahermeneutics. In addition, the article provides a panorama of methodological approaches to the discussion of the Romanticism problem in foreign literary research. The bulk of the article examines the controversy in the Soviet literary research of the 60-80s in the 20th century about the possible existence of 'new Romanticism' in the initial method of 'socialist realism'. This controversy has revealed two opposite approaches to the issue of 'Romanticism post Romanticism'. The first approach expressed in the statements of G. Pospelov, V. Vanslov N. Gulyaev, E. Maymin (et al.) categorically denied 'Romanticism post Romanticism' as "Romanticism had already existed before". The second approach, represented by A. Kireyeva, A. Ovcharenko, U.R. Focht, on the contrary, suggested the possibility (and even the regularity) of this phenomenon in the Soviet art. The article compares the seemingly typical Soviet polemic with the analogous polemic about Romanticism that erupted in the Russian literary criticism of the 30-40s in the 19th century. In 'the debate about Romanticism' the points of view both of 'the Romanticism deniers' referring to a unicity of (medieval) Romanticism - such as Nikolai Nadezhdin, and the supporters of the concept of 'Romanticism and Timelessness' - such as Vissarion Belinsky, were presented. The appearance of identical theoretical collisions in the Russian and Soviet literary research is inferred from the objective existence of the two types of thinking - analytical and synthetic - and the inevitability of ideological clashes of these types of thinking supporters. Analytical thinking is the ability to see and identify only those cultural phenomena that have been passed and digested by the mankind's previous experience, and the movement of culture is determined by the "eternal side of nature and the human spirit" for synthetic thinking (Belinsky, 1981).
\end{abstract}

Keywords: Romanticism, new Romanticism, realism, socialist realism, method, Hegelianism, V Belinsky, N. Nadezhdin, G. Pospelov, A. Kireyeva.

\section{Introduction}

The wording of the article theme, mentioning 'Neo Romanticism', indicates that this topic is methodologically justified only if Romanticism as general cultural (and, in particular, literary) phenomenon may remain beyond the boundaries of Romanticism as a concrete historical phenomenon.

A cultural direction of the late $18^{\text {th }}$ - early $19^{\text {th }}$ centuries is commonly referred to as 'Romanticism'. This direction has been extensively studied in many humanities researches. There is no doubt in such statements of possible researches as 'the Romanticism in German poetry of the nineties of the $18^{\text {th }}$ century', 'Romanticism in English poetry of the tenths of the $19^{\text {th }}$ century', 'Romanticism in French poetry of the twenties of the $19^{\text {th }}$ century'. This article is devoted to understanding the concept of 'Romanticism in Russian poetry of the second half of the $19^{\text {th }}$ - beginning of the $21^{\text {st }}$ century'. But can there be 'Romanticism of the twentieth century' or 'Romanticism of the twenty-first century'?

There are two answers to this question. The first answer is "No, absolutely impossible". The second option of the answer is "Yes, Romanticism beyond Romanticism is possible". As we see, the issue is controversial. 


\section{Research Methods}

The problem 'Romanticism beyond Romanticism' has always been on the periphery of the domestic and foreign literary criticism of the twentieth century; this poses considerable difficulties in the selection of methodological tools. During the twentieth century in the Soviet, in Russian and partly in the foreign literary research there fought two methodologies, realizing themselves in philological works of two competing schools: 'the sociological school' and 'the formal school'. We use the methods of both these schools.

It is impossible to speak about the features of discourse in a particular period of time in isolation from the sociopolitical and socio-psychological climate of the epoch. That is why we have an important tradition of 'sociological school' in literary criticism. On the other hand, we are actively using the achievements of the 'formal school' - especially its 'Opoyaz' school. Finally, on the practical side of the study, we apply the methodology of text hermeneutics taken in a particular variant, the philosophical metahermeneutics.

\section{Results and Discussion}

The problem of Romanticism boundaries as a socio-cultural phenomenon was actively studied in the foreign literature. Thus, in 1984 a book by V. Nemoianu "The Taming of Romanticism" was published (Nemoianu, 1984), in which the researcher actually reduced the entire Romanticism to a very vague term 'Biedermeier'.

Many of the foreign literary critics have tried to interpret the issue of Romanticism with the help of religion. In 1953 very important studies by M. H. Abrams "The Mirror and the Lamp" (Abrams, 1953) were published. For M. H. Abrams Romanticism is 'a zero' perception of the Judeo-Christian religion basis, at which the relationship between the Creator and the creation are translated into the sphere of relations between 'Me' and 'Not-me'. However, Neo-Marxists of the Freudian wing Jerome J. McGann condemned both the "religious" approach to Romanticism and Romanticism as such in his book "The Romantic Ideology" (McGann, 1983). For Jerome J. McGann the essence of Romanticism is in inappropriate flee of culture from social issues and in the unconscious repression of this process.

In the nineties of the $20^{\text {th }}$ century, the pendulum of attitude towards Romanticism in foreign literary criticism stopped in the middle. In his book "The Romantic Reformation" Robert M. Ryan criticized M. H. Abrams (for excessive 'teologizing' of Romanticism) and Jerome J. McGann (for uncritical acceptance of M. H. Abrams' theories) (Ryan, 1977). However, Robert M. Ryan still found romanticists prone to the religious quest. In contrast to him in the monograph "Romantic Atheism" an orthodox Marxist Martin Priestman named all romanticists 'infidels' in terms of high praise (Priestman, 1999). Then Daniel White (White, 2006) contrasted Romanticism to 'non-denominational Protestantism' and deconstructivists G. Hopps and J. Stabler condemned Martin Priestman for his dogmatic approach to postulates of Marxism (Hopps, Stabler, 2006).

However, both "Biedermeier" methodology of V. Nemoyanu and religious methodologies of M. Abrams, R. Ryan and D. White, as well as the Marxist methodology of Jerome J. McGann and Martin Priestman, and methodology for deconstructivists G. Hopps and J. Stabler - all these diverse methodologies leave open the possibility for the existence of 'Neo Romanticism', 'Romanticism beyond the concrete historical Romanticism'.

The basic part of this article focuses on how the problem of "Neo Romanticism" was solved in the Soviet literary research in the 60-80s of the $20^{\text {th }}$ century, as well as in the Russian criticism of the $30-40$ s of the $19^{\text {th }}$ century.

In 1966 "Iskusstvo" Moscow publishing house, significant for the Soviet literary science of that time, published a monograph by V. V. Vanslov "The Aesthetics of Romanticism" (Vanslov, 1966). Its significance is proved by the fact that there were references to this monograph by V. V. Vanslov in almost every Soviet scientific publication, dedicated to the theme of Romanticism, within 1967-1985. V. V. Vanslov considered Romanticism as a concrete historical direction in the global culture of the last decade of the $18^{\text {th }}$ - the first half of the $19^{\text {th }}$ centuries in detail. On the last pages of the monograph V. V. Vanslov raised the question about the possibility of 'Romanticism' existence in the Soviet literature and gave an unambiguous answer to it: "There is a point of view according to which a romantic method in the Soviet art should be spoken about in terms of its simultaneous coexistence with socialist realism as a byproduct of the principal method. This view seems to us erroneous. The admission, along with socialist realism as the main method, of a mere realism, romanticism and others (maybe classicism, naturalism?) not the basic, yet equally legitimate, independent methods is substantially equal to failure, at least in part, from artistic progress and the preservation of our modern methods born by the past eras and specific namely for them" (Vanslov, 1966).

V. V. Vanslov explained the reasons for the emergence of this (incorrect, in his opinion) point of view, reducing to paronyms confusion - 'romantic' and 'Romanticism': "... this concept did not catch on in the Soviet literary criticism. An integral part of socialist realism is not Romanticism, namely romance ..." (Vanslov, 1966). 
It should be noted that the appeal of V. V. Vanslov to the issue of Neo Romanticism was caused by echoes of a decade-old and even two decades-old literary and scientific controversy. In 1947, Alexander Fadeyev, a writer, in the article "Literary Criticism Tasks" split the current Soviet art into two components - the 'realistic' and the 'romantic' ones ("We must show our man truly and show the way he should be, to illuminate his future day. The first is the domain of realism, the second one of Romanticism" (Fadeyev 1947). V. V. Vanslov categorically rejected 'this dismemberment of the Soviet art methodology': "This point of view contains a distrust of realism as a method of work, to the possibility to reflect not only negative but also positive, not only the present but the future with its help. It condemns realism only to criticism of the present, considering that for the realization of the ideal of the future realism should come to aid romanticism. In fact, realism is not something wingless, purely empirical and only critical" (Vanslov, 1966).

The suggestions of this kind do not constitute an exception in the Soviet literary research of the 60-80s. The same arguments about the impossibility of preserving the historically outdated methods, about the "credibility of the socialist realism, able to include the romance in itself", about inappropriate mixing of paronyms - 'romantic' and 'Romanticism' can be found in scientific works of literary critics Nikolai Gulyaev (Gulyaev, 1974) and Eugene Maymin (Maymin 1975) or policy considerations of Yury Barabash, a party ideologist (Barabash, 1983). The uniformity of these arguments is the fact that they go back to a single original source - to the article of a Soviet-party ideologist G. N. Pospelov "On the Literary Trends (Regarding Article of B. G. Reizov) (Pospelov, 1958)", published in the "Philological Studies" journal. G. N. Pospelov, having entered into polemics with B. G. Reizov, clearly distinguished between the conceptual meaning of the terms 'Romanticism' and 'romance' (contrasting dualistic in nature concrete historical 'Romanticism' and the Soviet monistic 'romance'). G. N. Pospelov had many followers among the Soviet literary critics in the 60-80s of the $29^{\text {th }}$ century, but there were those who disagreed with him.

Five years after V. V. Vanslov's monograph publishing, Alla Kireyeva, a literary critic, entered a tough debate with orthodox views on the issue of 'Neo Romanticism' in the article "Methodological Background of Romanticism Study" (Kireyeva, 1971). She could not openly condemn the opinion of G. N. Pospelov, a senior functionary nomenclature; so the sarcastic anger of Alla Kireyeva hit V. V. Vanslov, retranslator of Academician G. N. Pospelov's ideas: "... the story makes its onward march, and Romanticism is theoretically stuck somewhere on the starting lines of the new century.

This concept varies as the canonical by many scientists. We can find it in the works of V. M. Friche, I. M. Nusinov, Andrejs Upits. It is developed and improved by V. V. Vanslov" (Kireyeva, 1971).

Indicative is the number of personalities in which A. Kireyeva puts a respectable culturologist V. V. Vanslov. Andrejs Upitts is a Latvian ultra-conservative writer, a belated retranslator of Stalinism. In 1959 he published a monograph "Issues of Socialist Realism in Literature" in Riga (Upīts, 1959), in which he declared Romanticism as the bourgeoisidealist trend, likened it to a 'rootless cosmopolitanism' and said that any romance is not only unnecessary for the Soviet literature, but also causes direct damage to the truthful depiction of reality, distracting writers from the national life. Even for a staunch enemy of 'Neo Romanticism' Yuri Barabash anachronistic monograph by Andrejs Upitts is a negative example (Barabash, 1983). Even more offensive in 1971, sounded the names of the authors of the early Soviet era Rappovets [a member of RAPP, Russian Association of Proletarian Writers] I. M. Nusinov and vulgar sociologist V. M. Friche; these researchers have been criticized in all Soviet scientific textbooks of the 60-70s as 'misguided'.

Alla Kireyeva counterposed the opposite view to the orthodox point of view on the 'Neo Romanticism': "Reflecting a reality, romanticism, as well as realism, classicism and other arts, has its own structure and its specific function that according to the law of form and content unity leads to the whole system of specific differences in the object image, the type of creative tasks, structures of image and style. This means that as relatively independent forms of life reflection, due to the needs of social practice, romanticism and realism are not opposed, and do not replace each other. They are united in terms of the social problems of the reader's/the viewer's consciousness formation. Therefore, romanticism cannot be imprisoned within the narrow limits of the historical and literary movement. It appears wherever there is a need for it, but appears, of course, in new forms and new content, because the dialectic of the development does not admit repetitions" (Kireyeva, 1971).

G. N. Pospelov and his disciples (V. V. Vanslov, N. Gulyaev, E. Maymin, Yu. Barabash et al.) thought that 'Neo Romanticism within the Soviet literature', as well as any 'Neo Romanticism', in general, is impossible, since romanticism as a cultural direction was determined by unique, non-recurring socio-historical background. A. Kireyeva and some other literary critics (such as A. Ovcharenko (Ovcharenko, 1969) and U. Focht (Focht, 1967), by contrast, proved the possibility (and even regularity) of the existence of 'socialist romanticism' because a creative methodology is determined not by the social prerequisites but by the needs of the public practice in appropriate forms of life reflection.

Views of "Pospelov's school" and views of Alla Kireyeva (or Ovcharenko) regarding the issue of 'Neo Romanticism' were the extreme ones. Most Soviet literary critics of the 60-80s of the twentieth century took moderate positions. So, A. Pavlovsky in the article "On 'romantic realism version' (To the disputes on Romanticism in the Soviet literature)" 
(Pavlovsky, 1978) was careful to note: "... the concept of Romanticism, however, cannot be dispensed with, so to speak, entirely on the sole grounds that some literary critics associate it too closely with the Romanticism of the $19^{\text {th }}$ century"(Pavlovsky, 1978). A. A. Mikeshin in the article "The Problem of Historical Fates of Russian Romanticism in the Soviet Literary Criticism" (Mikeshin, 1971) outlined three meanings of the word 'Romanticism' - three doubtless and two disputable ones. To the doubtless meanings of the word 'Romanticism' A. Mikeshin referred (other than designations of historical trends in literature and commonly understood natural synonym for 'romantic') the artistic method, which was treated by the writers of the second half of the $19^{\text {th }}$ - early $20^{\text {th }}$ centuries. Controversial meanings of the word "Romanticism, according to A. A. Mikeshin, are "independent direction in the Soviet literature during the 20s" and "romantic stylistic origin in the literature of socialist realism" (Mikeshin, 1971).

Apparently, at the end of the 60s of the twentieth century the viewpoint of "moderate" literary critics was gradually canonized in the Soviet science. The indirect evidence of this are the wording of the interpretation of the word 'romance' in all the dictionaries, published in the 70s and 80s of the twentieth century: all of them include the meaning of "Romanticism as a method used in some cases, by socialist realists". In the short term, 'moderate' literary critics won. However, their balanced position did not give a clear answer to the question: whether 'the new Romanticism', Romanticism going beyond the concrete historical trends is possible? This issue involves only two alternative answers "no, it is not possible" or "Yes, it is possible". By and large, in the history of literary research there were two irreconcilable positions - the point of view of "Pospelov's school" and the view of unconditional supporters of the possible existence of 'Neo Romanticism' (such as A. Kireyeva and A. Ovcharenko) - the position of saying 'no' and the position of saying 'yes'.

If we look at the situation in the Russian literary criticism of the second quarter of the $20^{\text {th }}$ century, we find that the Soviet theoretical dispute between the opponents of the "Neo Romanticism" and supporters of the "Neo Romanticism" had a counterpart in the previous era of concrete romantic Romanticism. Critics of the second quarter of the $19^{\text {th }}$ century, had a negative attitude to Romanticism, denied not only the possibility of the 'Neo Romanticism', but also the possibility of Romanticism in those forms in which it is familiar to us. Rejecting the 'Neo Romanticism', they denied the romance itself, operating the same reasons that a century later G. N. Pospelov and V. V. Vanslov would use. These critics claimed that 'modern Romanticism', Romanticism in the $19^{\text {th }}$ century is impossible, since Romanticism had already existed in the Middle Ages, and the historic bases and their corresponding forms of culture cannot be repeated for humanity again.

Thesis of Nikolai Nadezhdin, a literary critic and literary historian "On the Origin, Nature and Destiny of Poetry Called Romantic" (Nadezhdin, 1979) was published in 1830, in Latin as a separate book and successfully defended on April 22 of the same year at Moscow University. In this research, Nikolai Nadezhdin rejected the possibility of romantic literature as a phenomenon of modern times. The chain of consistent evidence of the 'impossibility of Romanticism' was set in the "Theses", completing a thesis of N. Nadezhdin:

1. Where there is life, there is poetry.

2. Poetry is unified in itself, it takes many forms.

3. The forms of poetry are determined by the spirit of the time, to which it relates.

4. Three forms of poetry had existed until now: primitive, classical and romantic.

5. Romantic poetry has finished its existence and now does not exist.

6. The period of romantic poetry is limited by time, having the name of the Middle Ages.

7. Romantic poetry was looking for the highest beauty within a man.

8. The spirit of romantic poetry flowed directly from the spirit of the Middle Ages.

9. The world in which we live is fundamentally different from the Middle Ages.

10. Restoration of romantic poetry is impossible in our time.

11. Poetry, that now has appropriated the name of romantic, is only an imitation of it.

12. Pure imitation of romantic poetry is applied only to the detriment of our time and dishonors it.

13. The study of classical poetry is the best medicine for the treatment of diseases caused by the imitation of Romanticism

14. Our motherland should be particularly zealous to protect itself from infection of pseudo-romanticism that can be achieved by classical antiquity study" (Nadezhdin, 1979).

N. Nadezhdin tried to prove the impossibility of contemporary Romanticism based on the natural philosophy of Schelling. According to N. Nadezhdin, Romanticism had already existed in the the Middle Ages, and then it was determined by its proper time ("it was arising directly from the spirit of the Middle Ages"). What is known as the definition of "Romanticism" is an exotic "Romanticism post Romanticism", which is unnatural, since there are no spiritual prerequisites for its implementation (because the world of the $20^{\text {th }}$ century in which contemporaries of $\mathrm{N}$. Nadezhdin live, differs radically from that of the Middle Ages).

The theory of Nikolai Nadezhdin fell in exactly with his political views: N. Nadezhdin was a convinced monarchist, 
adhered to the attitude that was regulatory for his time to "Orthodoxy, autocracy, nationality" and saw the revolutionary phenomenon in Romanticism, undermining the foundations of the state (not by chance Nadezhdin first of all opposed the late French "furious" Romanticism). Disciple and collaborator of Nikolai Nadezhdin, but at the same time, his ideological adversary, the radical oppositionist and Westernist Vissarion Belinsky, considered 'the problem of Romanticism' in the opposite way. As a theorist of 'natural school' (i.e., realistic), V. Belinsky could not unconditionally accept Romanticism. He estimated the romantic 'mainstreamof the 30s-40s of the $19^{\text {th }}$ century extremely negative (the prose of Alexander Bestuzhev-Marly, poetry of Vladimir Benediktov, etc.). However, V. Belinsky never tied literary forms to the changing socio-historical basis by rigid connection: he was rather an adherer of the Hegelian school of philosophy than of Shellingian, considering the issue of the relation of being and forms of culture much more flexibly and differentially.

Extensive work by Vissarion Belinsky "The Works of Alexander Pushkin" (Belinsky, 1981) was completed in 1843 and it was published in the sixth issue of the journal was published in the journal Otechestvennye zapiski [Notes of the Fatherland] of that year. The second chapter of "The Works of Alexander Pushkin" was devoted to Karamzin, "Karamzinian period of Russian literature", Dmitriyev, Krylov, Ozerov, Zhukovsky, Batyushkov and Romanticism in general. Attention is drawn to the fact that V. Belinsky fully expanded the concept of 'Romanticism' and liquidated its historically-time (and even conceptual) borders, "Romanticism is belonging not only to the art, not only to the poetry: its source is in what is the source of the art and poetry - in life. Life is where the man is, and where the man is, there is Romanticism. In its closest and most significant meaning Romanticism is nothing less than the inner world of the human soul, the hidden life of his heart. The chest and the heart of man include a mysterious source of Romanticism; feeling, love is the manifestation or effect of Romanticism, and because almost every man is romantic" (Belinsky, 1981).

Concept of V. Belinsky implies eternal existence of 'Romanticism beyond Romanticism'; it should be noted that this 'Romanticism beyond Romanticism' allows including not only 'Romanticism before Romanticism' (e.g. 'Greek Romanticism'), but also a hypothetical 'Romanticism post Romanticism ' (Belinsky, 1981).

Statements of the $19^{\text {th }}$ century critic Vissarion Belinsky and the $20^{\text {th }}$ century critic Alla Kireyeva coincide almost word for word ("...Romanticism is not heritage and ownership of any one country or epoch: it is an eternal side of nature and the human spirit, it did not die after the Middle Ages, but only transformed") as V. Belinsky stated; "...Romanticism cannot be imprisoned within the narrow limits of the historical and literary movement. It appears wherever there is a need for it ..." A. Kireyeva wrote).

\section{Summary}

The argument of the critics of the $19^{\text {th }}$ century about 'Romanticism beyond the Middle Ages' and the argument of the critics of the $20^{\text {th }}$ century about 'Romanticism beyond Romanticism' is one and the same eternal dispute arising out of the dissimilarity of two methodologies related to the underlying, axiomatic features of different types of thinking. The first kind of thinking is analytical, catalogizing. It sees, recognizes and acknowledges only those cultural phenomena that have been passed, interpreted and classified by the previous experience of mankind. It is naturally determined that the supporters of this thinking are always lagging behind in the act of codification of modern culture: for them "culture is always that what was yesterday, but is not today". As a rule, conservative, protective views in socio-political terms are typical for the supporters of this type of thinking, and such people tend to Classicism in their aesthetic views (in its reference version or in the new 'socialist realist' version).

The second type of thinking is synthetic, summarizing. For the supporters of the type of thinking cultural phenomena are determined not by the established laws of socium development, but by a certain 'eternal side of nature and the human spirit'. Synthesis adherents tend to innovations in their political (V. Belinsky) and aesthetic (A. Kireyeva) aspirations. Even the limiting scope of Marxism in the Soviet literary criticism could not be an obstacle to the realization of synthetic thinking discourse: Marxism was based on Hegelianism and Hegelianism - the doctrine built on a synthetic vision of 'the evolution of the absolute spirit'; Alla Kireyeva made use of the 'residual Hegelianism in Marxism' to approve 'Romanticism beyond Romanticism'.

The question 'Is 'Romanticism beyond Romanticism' possible?' is answered by the analytical discourse as follows: "No, it is not possible, since the times of Romanticism have passed before", but the synthetic discourse gives the opposite answer: "Yes, it is possible, because the origins of Romanticism are eternal and everlasting". Of course, different researchers may interpret the 'eternal and everlasting origins' of Romanticism in different terms. For Vissarion Belinsky 'Romanticism is nothing less than the inner world of the human soul, the hidden life of his heart'; for Alla Kireyeva Romanticism is "an independent form of life reflection conditioned by the needs of social practice". Finally, in modern literary criticism there is a viewpoint that takes Romanticism out of a special type of romantic world outlook not rooted in a particular historical period (Ankudinov 2013). According to this point of view, romantic world outlook can 
manifest itself at all times, therefore, Romanticism as an expression of romantic world outlook is eternal.

\section{Conclusion}

The polemics between the Soviet literary critics about the 'new Romanticism' occurring in the $60-80$ s of the $20^{\text {th }}$ century had common aesthetic, philosophical and socio-political prerequisites, dating back to the previous conflicts of the $19^{\text {th }}$ century. The reason for the extemporal nature of this debate is related to the existence of two types of thinking analytical and synthetic - and antagonistic character of the conflict between these two types of thinking.

\section{References}

Abrams, M. (1953). The Mirror and the Lamp: Romantic Theory and the Critical Tradition. Oxford. (429 p.)

Ankudinov, K. N. (2013). K voprosu o soderzhanii metodologicheskogo kontsepta 'romantizm posle romantizma' [To a Question about the Content of the Methodological Concept of 'Romanticism post Romanticism ']. Bulletin of the Adyghr State University. Vypusk 1 (144). - Maykop: AGU Press. (pp. 18-23) [in Russian].

Barabash, Yu. Ya. (1983). Voprosy estetiki i poetiki [lssues of Aesthetics and Poetics]. - Moscow: Sovremennik. (416 p.) [in Russian].

Belinsky, V. G. (1981). Sochineniya Aleksandra Pushkina. «Otechestvennye zapiski» [The Works of Alexander Pushkin. "Notes of the Fatherland"], 1843, Vol. 6. Sobranie sochineniy: in 9 Vols. 9 - Moscow: Hudozh. lit. (pp. 74-544). [in Russian].

Fadeyev, A.A. (1975). Zadachi literaturnoy kritiki (1947) [Problems of Literary Criticism (1947)]. Voprosyi teorii iskusstva. - Moscow: Politizdat. (pp. 28-50) [in Russian].

Focht, U. R. (1967). Nekotoryie voprosy v teorii romantizma [Some Questions in the Theory of Romanticism]. Problemyi romantizma. Moscow: Iskusstvo. (pp. 77-91) [in Russian].

Gulyaev, N. A. (1974). Russkiy romantizm: uchebnoe posobie [Russian Romanticism: a tutorial]. - Moscow: Vysshaya shkola. (364 p). [in Russian].

Hopps, G., Stabler, J. (Eds.) (2006). Romanticism and Religion from W. Cowper to W. Stevens. - Hampsire, England: Burlington, USA. $(820$ p.)

Kireyeva, A. F. (1971). Metodologicheskie predposyilki izucheniya romantizma. Iz istorii russkogo romantizma [Methodological Background of Romanticism Study. From the History of Russian Romanticism]. - Kemerovo. (pp. 51-58) [in Russian].

Maymin, E. A. (1975). O russkom romantizme [On Russian Romanticism]. - Moscow: Prosveschenie. (246 p.) [in Russian].

McGann, J. (1983). The Romantic Ideology. - Chicago; London. (480 p.)

Mikeshin, A. M. (1971). Problema istoricheskikh sudeb russkogo romantizma v sovremennom literaturovedenii. Iz istorii russkogo romantizma [The Problem of Historical Fates of Russian Romanticism in Contemporary Literary Criticism. From the History of Russian Romanticism]. - Kemerovo. (pp. 3-50). [in Russian].

Nadezhdin, N. I. (1979). O proiskhozhdenii, prirode i sudbakh poezii, nazyivaemoy romanticheskoy (1830) [On the Origin, Nature and Destiny of Poetry Called Romantic (1830)]. Literaturnaya kritika. Estetika. [Literary Criticism. Aesthetics] - Moscow: Khudozhestvennaya literatura. (pp. 118-253) [in Russian].

Nemoianu, V. (1984). The Taming of Romanticism: European Literature and the Age of Biedermeier. Harvard University Press. (200 p.)

Ovcharenko, A. I. (1969). Romantizm $\vee$ sovetskoy literature [Romanticism in the Soviet literature]. Sotsialisticheskiy realizm $i$ sovremennyy literaturnyy protsess. - Moscow: Sovetskiy pisatel. pp. 49-92) [in Russian].

Pavlovskiy, A. I. (1978). O «romanticheskom izvode realizma» (K sporam o romantizme v sovetskoy literature) [About "Version of Romantic Realism" (to disputes on romanticism in Soviet literature)]. Russkyy romantizm [Russian Romanticism]. - Leningrad: Nauka. (pp. 262-276). [in Russian].

Pospelov, G. N. (1958). O literaturnykh napravleniyah (po povodu stati B. G. Reizova) [On the Literary Trends (about the article by B. G. Reizov)]. Filologicheskie nauki. No.1. (pp. 100-113) [in Russian].

Priestman, M. (1999). The Romantic Atheism: Poetry and Free Thought. Cambridge. (580 p.)

Ryan, R. (1977). The Romantic Reformation: Religious Politics in English Literature. Cambridge. (242 p.)

Upit, A. (1959). Voprosy sotsialisticheskogo realizma v literature [Issues of Socialist Realism in Literature ]. - Riga: Latvgosizdat. (907 p). [in Russian].

Vanslov, V. V. (1966). Estetika romantizma [Aesthetics of Romanticism]. - Moscow: Iskusstvo. (404 p). [in Russian].

White, D. (2006). Early Romanticism and Religious Dissent. Cambridge. (424 p). 